alothane 0.5 to I per cent. She was allowed to breathe spontaneously. The recovery period was identical to that of Case 2, except that she failed to respond to verbal command on admission to the Recovery Room. She also responded well to diazepam.

There was no hypoxia or hypercarbia during any of the anaesthetic procedures.

Prolonged sleep and rigidity with apnoea and cyanosis should now be added to the list of known reactions to Alfathesin.

Emil G. Bishay, M.D., B.Ch., D.S.

D.A., C.S.P.Q., D.A.B.A., F.A.C.A.

Staff Anaesthetist

The Reddy Memorial Hospita!

Montreal, Quebec

\section{Serum Cholinesterase Activity Following} ANAESTHESIA

Sir,

I was interested to read the article on serum cholinesterase activity following enflurane analesthesia by Kaniaris, Fassoulaki and Liarmakopoulou in the November 1978 issue of the Canadian Anaesthetists" Society Journal. In a smaller, less well controlled study, 1 have reached the same conclusion, demonstrating an initial small drop in cholinesterase activity one hour after starting enfurane anaesthesia, with return to normal 24 hours later. In addition to ten patients having enfurane, I also looked at five patients having halothane and five patients having spinal anaesthetics.

The 20 patients, ranging in age between 24 and 83 years were premedicated with diazepam 10-20 mg orally and were undergoing simple urological, orthopaedic and general surgical procedures in whihe the average estimated blood loss was less than $50 \mathrm{ml}$. Those patients having general anaesthesia were given thiopentone $250-500 \mathrm{mg}$ and anaesthesia was maintained by spontaneous ventilation, through a circle carbon dioxide absorber circuit, with 66 per cent nitrous oxide with oxygen and either 1 to 3 per cent of enflurane or 1 to 2 per cent halothane. Those patients having spinal anaesthetics were given a subarachnoid injection of tetracaine $12-15 \mathrm{mg}$ in 10 per cent dextrose. All patients had an intravenous infusion of lactated Ringer"s solution of which. in the first two hours. the enflurane patients received $400 \mathrm{ml}$, the halothane patients $500 \mathrm{ml}$ and the spinal patients $900 \mathrm{ml}$. The average length of anaesthetic was 56 minutes with enflurane and 76 minutes with halothane. while in the spinal anaesthetic group the average operating time was 67 minutes. Bloud samples were taken preoperatively and at one hour, two hours. four hours and $\mathbf{2 4}$ hours after the start of anaesthesia. Serum was obtained by centrifugation of clotted blood and it was then frozen until an estimation of cholinesterase level could be made. which was done using acetyl thiocholine as a substrate.

The results are summarised in the Table.

Thus it appears that halothane and spinal anaesthesia should be considered with enflurane and methoxyflurane' as capable of causing a small acute drop in serum cholinesterase activity. which returns to normal within 24 hours.

An older paper by Mclntyre and Campbell? was primarily concerned with the effects of neostigmine on serum cholinesterase activity during a thiopentone, succinyl choline, nitrous oxide, oxygen, halothane and curare anaesthetic, which was not shown by patients who had fentanyl and droperidol rather than halothane. In Palahnuik's methoxyflurane study, control patients who had thiopentone, succinyl choline, nitrous oxide and oxygen, and curare, showed levels of cholinesterase activity to be slightly depressed initially, but raised above normal at two hours and 24 hours.

Another study ${ }^{3}$ suggests that an initial drop in cholinesterase activity is common following

Serum Cholinesterase Activity

\begin{tabular}{lccccc}
\hline & Preop & 1 hour & 2 hours & 4 hours & 24 hours \\
\hline $\begin{array}{c}\text { Enflurane } \\
\text { (10 patients) }\end{array}$ & 3452 & 3130 & 3274 & 3224 & 3442 \\
$\begin{array}{c}\text { Halothane } \\
\text { (5 patients) }\end{array}$ & 2627 & 2483 & 2863 & 2517 & 2946 \\
$\begin{array}{c}\text { Spinals } \\
\text { (5 patients) }\end{array}$ & 3431 & 3287 & 3210 & 3173 & 4363 \\
\hline
\end{tabular}


surgery and anaesthesia. Perhaps the effects of surgery and anaesthesia on liver perfusion are more important than the effects of anaesthetic drugs on enzyme activity.

David J. Wright, M.B., B.S., F.F.A.R.C.S.

Departmenl of Anaesthetics

The Royal Infirmary

Edinburgh, Scotland

\section{REFERENCES}

1. Palahniuk, R.J. \& Cumaing, M. Serum cholin. esterase activity following the use of methoxy* furane in obstetrics. Anesthesiology 47, 520-522 furane in obstetrics. Anesthesiology 47, 520-522 (1977)

2. MClNTYRE, J.W.R. \& CAMPBELL. D.J. Serum cholinesterase in anaesthesia with reference to neostigmine, fentanyl and dihydrobenzpiridol. Can. Anaes. Soc. J.. 13, 557-561 (1966).

3. Kamayev. M.F. \& Viktorenko. V.G. Effect of surgical trauma and intubation anaesthesia on the cholinesterase activity. Klinicheskaia Khirurgiata. pp. 9-12 (1976). 